\title{
COVID-19 Prevention in Elementary and Secondary Schools in Bayelsa State, Nigeria
}

\section{Helen Idubamo Wankasi (PhD)*, Tari Amakoromo and Data Aluye-Benibo}

\author{
Department of Community Health Nursing, Faculty of Nursing Sciences, Niger Delta \\ University, Wilberforce Island, Bayelsa State, Nigeria.
}

*Orcid.org 0000-0002-8403-5555; Email: hidubamo@gmail.com

\section{Cite this article:}

Helen I.W., Tari A., Data A. (2021), COVID-19 Prevention in Elementary and Secondary Schools in Bayelsa State, Nigeria. International Journal of Public Health and Pharmacology 2(1), 15-34. DOI: 10.52589/IJPHPN6XSQBFU.

\section{Manuscript History}

Received: 5 June 2021

Accepted: 5 July 2021

Published: 26 July 2021

Copyright $\odot 2020$ The Author(s). This is an Open Access article distributed under the terms of Creative Commons AttributionNonCommercial-NoDerivatives 4.0 International (CC BY-NC-ND 4.0 ), which permits anyone to share, use, reproduce and redistribute in any medium, provided the original author and source are credited.
ABSTRACT: Introduction: Corona virus disease affects all segment of present-day society regardless of age, sex and societal status as well as environment. Objective: This article explored possible measures that would prevent the spread of COVID-19 in elementary and secondary school environments. Method: A qualitative study utilizing exploratory descriptive approach. Online social media platforms-were exploited for data collection with voluntary, yet eligible 36 participants drawn from the teaching and healthcare fields between $1^{\text {st }}$ of April to $4^{\text {sht }}$ of May 2020. Data analysis: Participants responses were transcribed verbatim and a line-by-line thematic analysis was conducted to identify emerging themes. Finding: Five themes and thirteen (13) sub-themes emerged namely: Preventive measures: awareness and knowledge creation: effective information and management system: availability of drugs and other amenities: monitoring and evaluation. Conclusion: If the aforementioned measures are adopted, though COVID-19 will leave with mankind as other infectious diseases for a period until science can discover means to eradicate, the fast spreading rate will be reduced to a very low ebb and educational activities would be uninterrupted, since there would not be further closure of elementary and secondary schools in Bayelsa State.

KEYWORDS: COVID-19, Elementary, Secondary Schools, Prevention 


\section{INTRODUCTION}

Both empirical and unempirical evidences indicate that in the past year the world has experienced a number of issues, prominent of these is the corona virus, popularly known as COVID-19 pandemic (Wang et al 2020). COVID-19 has affected every segment (all levels educational institutions not exceptional) of human endeavour in both developed and emerging worlds. Though, it is widely established that children and youths are less vulnerable to the virus sequel to their active immunity and constant bodily activity. Schools are made up of not only pupils and youths, but teaching, non-teaching staff with underlying health issues that present such category vulnerable. This article intends to recommend measures to prevent the spread of the virus in elementary and secondary schools in Bayelsa State, Nigeria.

\section{Background of Study}

(Shereena, Khana, Kazmic, Bashira and Siddiquea, (2020) stated that Corona virus has thorns and crown like outlook superficially, hence the name corona depicts crown and coronation. It was also found out that Coronavirus belongs to the Corona viridae family in the Nidovi-rales order. Shereena et al. (2020) describe Coronaviruses as; minute organism (65-125 nm) in diameter; with a single-stranded RNA; weighs between 26 to $32 \mathrm{kbs}$ in length as seen in (Fig. 1) below and it is also divided into four (4) subgroups namely: alpha (a), beta (b), gamma (c) and delta (d) coronavirus. This novel virus was named as Wuhan coronavirus or 2019 (2019nCov) in $b$ group of corona viruses named by Chinese researchers. The name depicts the year the virus became a substance of public health importance. The International Committee on Taxonomy of Viruses (ICTV) named the virus as SARS-CoV-2 and the disease as COVID19 (World Health Organisation`s (WHO) COVID-19 response, 2020).

\section{Severe acute respiratory syndrome coronavirus 2 (SARS-CoV-2)}

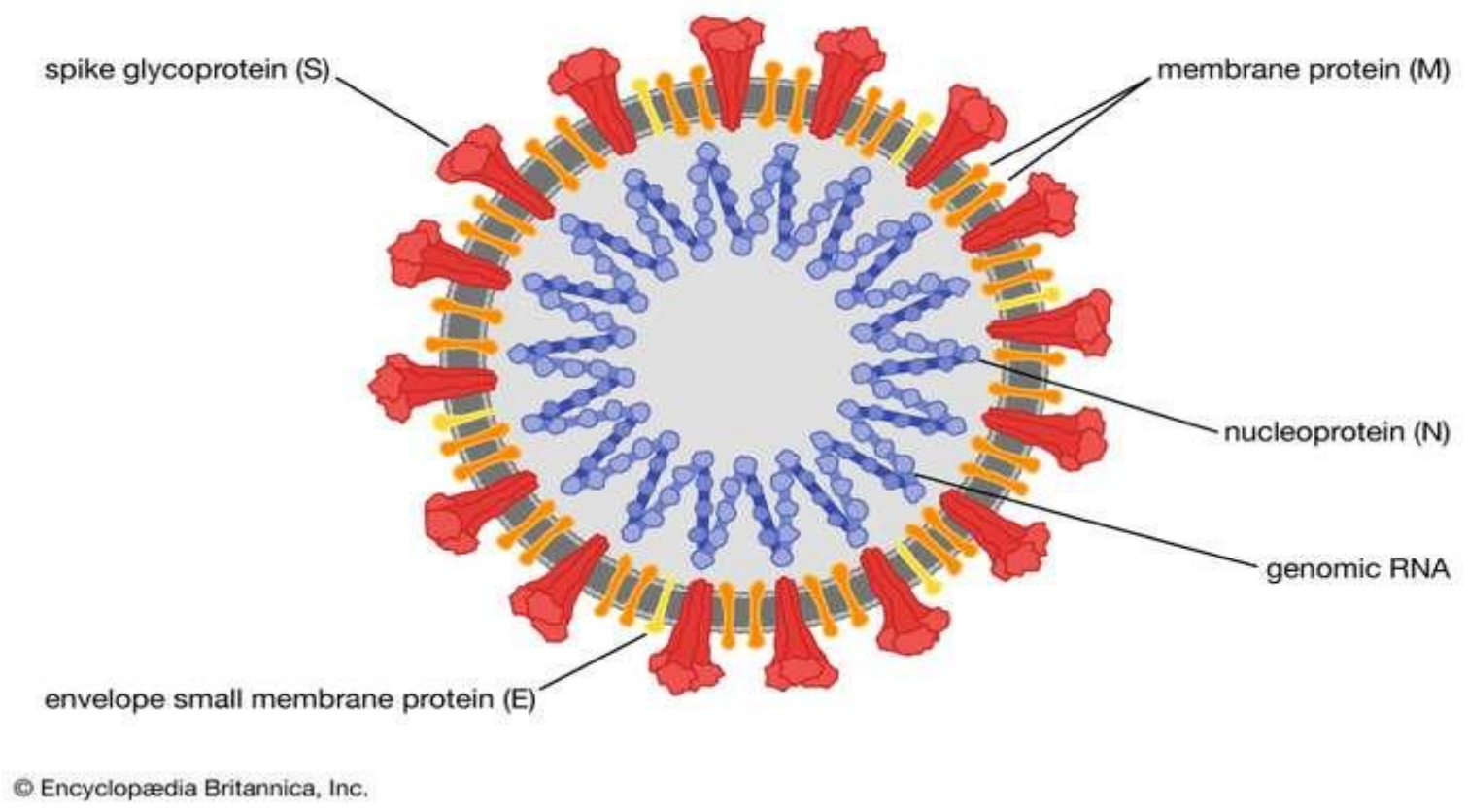

Figure 1: The coronavirus SARS-CoV-2, an excerpt from Encyclopadia Britannica, Inc./Patrick O'Neill Riley 
Shereena et al. (2020) postulate that coronavirus infection presents in several forms such as: severe acute respiratory syndrome coronavirus (SARS-CoV), H5N1 influenza A, H1N1 2009 and Middle East respiratory syndrome coronavirus (MERS-CoV). In all of these forms, the virus affects the human lungs, causing acute lung injury (ALI), acute respiratory distress syndrome (ARDS) due to gradual pulmonary failure which leads to death (Shereena et al. 2020). Although initially proponents thought the virus infect only animals until the world witnessed SARS outbreak caused by SARS-CoV, 2002 in Guangdong, China (Riou \& Althaus 2020). At the end of 2019, from a business hub in Wuhan an outbreak of coronavirus became full blown, with thousands of lives lost within few months (Sowole, Ibrahim, Sangare, \& Johnson, 2020).

Ever since the emergence, there has been an unprecedented spread of the diseases in a global perspective (Sowole et al 2020; An-Rong Guo 2020). In a bid to contain the rapid spread, WHO raised alarm as the disease was becoming beyond human containment, thus developed a framework that would prevent the transmission of the virus through animals to human being fundamentally on infection control, prevention and laboratory testing as well as build national capacities in early January, 2020. As part of the prevention framework, about 48 funders from different countries in February, 2020, under the auspices of WHO convened a "Global Research and Innovation Forum". The programme was attended by over 300 experts and 150 online participants who assessed the level of knowledge, identified gaps and collaborated to fund and research on key areas of concern with equitable access as a fundamental underpinning principle. The areas included: etiology of the virus, epidemiological studies and clinical characterization and others. The Forum was convened in consonance with the WHO`s parameters, aimed at fast-tracking diagnostics, vaccines production and therapeutics as well as prevention processes for this coronavirus in all segments of human life. Despite these drastic measures, the spread of the virus got to its peak in November 2020 not minding the lockdown, which was WHO's prescribed standard of precautions taking by individuals, families and organisations. In addition, as an update in December, 2020, WHO highlighted global figures below as 216,293,544 affected learners $\mathbf{1 2 . 4 \%}$ of total enrolled learners and 26 country-wide closures, which gives a total number by countries/territories between 17 February 2020 and 30 June 2020, as in the chart below. 


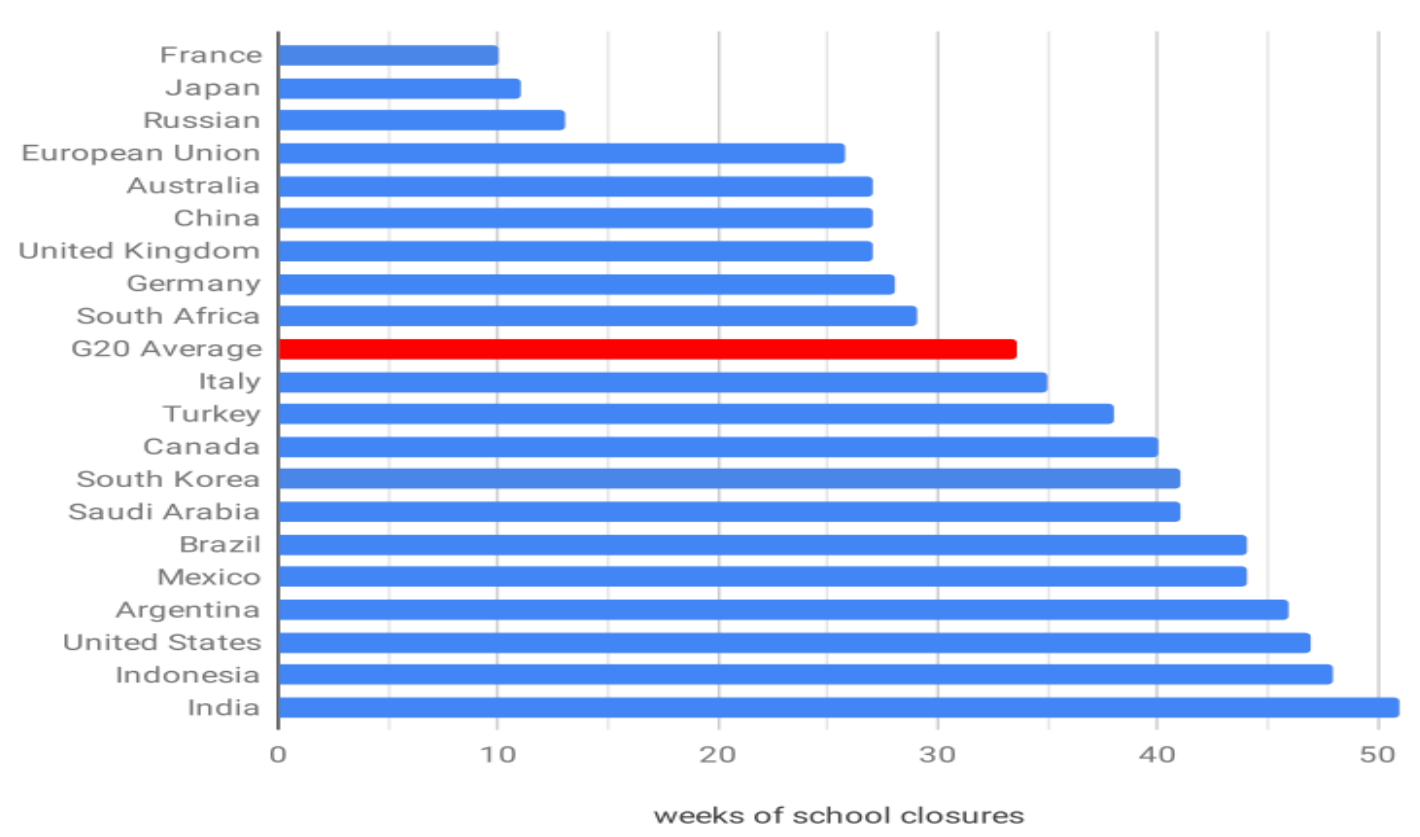

Figure 2. Number of countries with school closures due to COVID-19. An excerpt from pandemic_in_G20_countries.svg

Below is the children and youth out of school due to COVID-19 closures and young people classified as not in education, employment or training (NEET) as illustrated below.
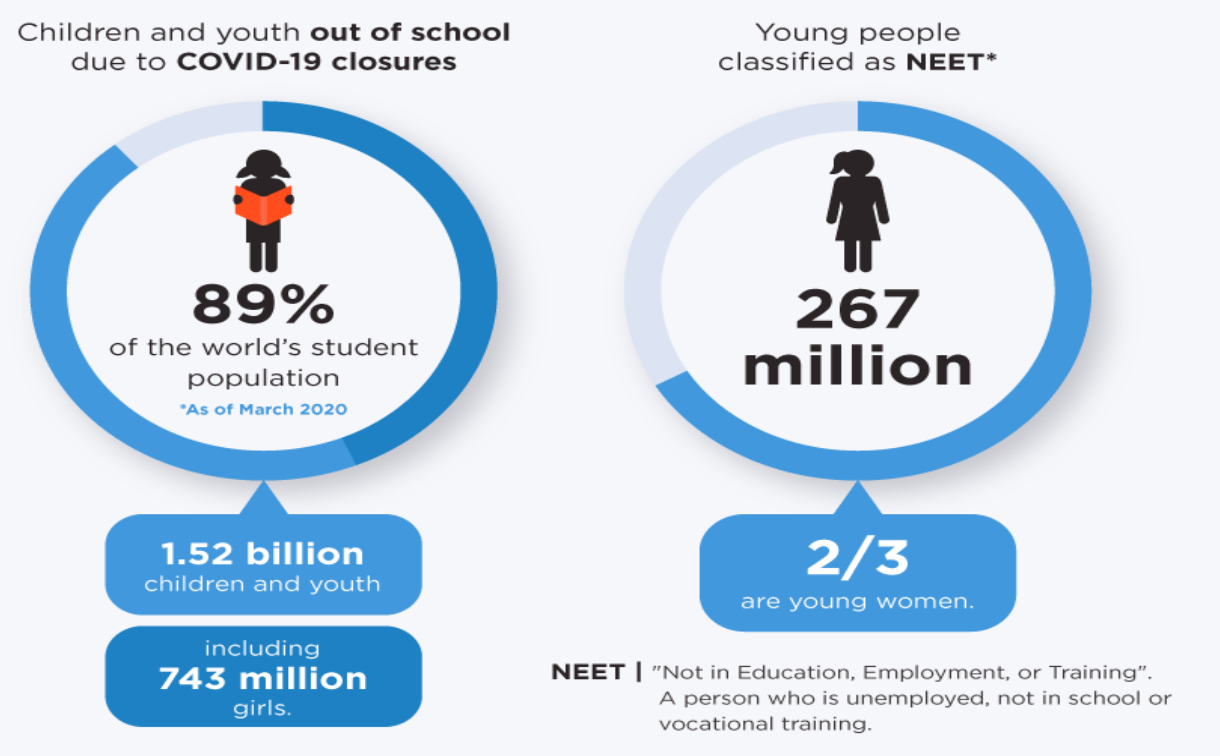

Figure 3: Percentage of school children affected by school closure. Source

Source: https://en.wikipedia.org/wiki/Impact_of_the_COVID-

19_pandemic_on_education\#/media/File:School_closures_due_to_the_Covid-19_ 
Children and youth out of school due to COVID-19 closures and young people classified as NEET update indicates part of the debilitating impact of COVID-19 on social and economic life.

Earlier statistics shows, well over 40 million children had enrolled in elementary and secondary schools in the past decade and 12 million attend school daily; spend an average of 9 months out of 12 months in the year, 5 days out of 7 days in the week and a minimum of 7 hours in the 12 hours' day time in the day (RSA Health Basic Education, 2009). In another global perspective, over $90 \%$ of children in the primary school age, and over $80 \%$ of children in the lower secondary school age are enrolled in school according to UNICEF (2018). These estimations imply that, 13-15 years of a child's life is spent within elementary and secondary school environments. In addition, report shows that, school children constitute a significant population (44\%) in Nigeria (World Bank, 2015). Presently, the number of learners enrolled from pre-primary to upper-secondary education is $831,021,742$ and number of learners enrolled in tertiary education programmes is 128,207,915. The interpretation is that; whatever health challenges this captive population faces is of huge public health importance.

Elementary and secondary schools are environments where children are expected to learn in good health to make optimal grades in order to accomplish their life goals (National Policy on School health, 2009). Viner, Russell, Croker, Packer, Ward, Stansfield and Booy (2020) study on all school closure and management practices during coronavirus outbreaks: a rapid systematic review indicates that, 107 countries had implemented national school closures as at March 18, 2020. It was unknown whether school closure measures are effective in coronavirus outbreaks as at then. The 616 retrieved studies revealed that, effectiveness of school closures and social distancing practices during coronavirus outbreaks were most appropriate.

In the United States of America (USA), a multistate survey, led by the USA Centre for Disease Control (CDC), found that, $26 \%$ of children and young adults aged 18-34 years reported not having "returned to their usual state of health 14-21 days after being treated for any COVID-19 related illnesses". Though this study was in the university, but could be applied into the elementary and secondary schools, in the sense that, if these matured group can be affected so adversely, then prevention seems to be the best option to curtail the spread in elementary and secondary schools that constitute population of younger children. Specifically, Georgia in the USA, 260 cases among staff and campers (6-19 years) in an overnight camp (Yamey \& Walensky, 2020). In both instances, preventive measures were weak during the widespread community transmission of SARS-CoV-2, thus, preventive and protective measures in schools are very important and are needed.

Anecdotal source states that in Asia, school closures were deployed rapidly across Hong Kong in other to halt the fast spread of COVID-19. Whereas, there was a contrary action in mainland China, and Singapore. The contrary act demonstrated in the two countries suggests that, there are no relative contribution of school closures to transmission control, implying that, school closures did not contribute to the control of the epidemic after all, meaning, closure should be considered least option to prevent the spread of the virus. For instance, recent modelling studies of COVID-19 predict that, school closures alone would prevent only $2-4 \%$ of deaths, much less than other social distancing interventions. Not only that, in the Middle East, Israel: 178 cases (153 students 12-18 years and 25 staff) in a high school 10 
days after reopening; affected classes were crowded with few measures in place to prevent the spread.

Again, a Republic of South African (RSA) Broadcasting Cooperation (SABC) radio programme decried the continuous rise in COVID -19 cases in the second wave, in which it was mentioned that the RSA, UK and Brazil strains of COVID-19 could be more contagious in the coming days if no drastic measures are taken. As such, RSA authorities in a cabinet meeting (one of their plenary sessions) mandatorily ordered amongst several other measures in-door and out-door gatherings including schools must not continue for another two weeks. However, there are several actions and requirements that should be reviewed and put in place to prevent the introduction and spread of COVID-19 in schools and into the community; and to ensure the safety of children and school staff while at school. These must be complied in no little measure, given, RSA duly elected authorities have legitimate powers and mandate to make such legal decisions regarding schools closure and the legitimacy to order their execution. Meaning, there is no debatable issue as to the ravaging effect of the virus towards mankind, as a result, it needs lawful intervention to make pronouncements aimed at containing the virus. Thus, this study explored stakeholders` recommendations that would prevent the spread of the virus in elementary and secondary schools. Again, the Humanitarian, development and government partners (HDGp) in Nigeria are already experiencing some challenges in the implementation of response to COVID19. Such challenges ranges from funding requirements, protection of staff and capacity to deliver $100 \%$ while working from home. On account of these significant challenges, the HDGp are implementing a range of interventions.

Presently, there are over .......cases in Bayelsa with limited literature as regards to the subject under study as well as the persistent rise in the number of cases, pre-empt the need to explore the opinions of teachers and healthcare professionals. These stakeholders can respond to the question put forwarded at their convenience and comfort zone as a result of movement restriction in gathering which hinders movement for data collection. Teachers and healthcare professionals are preferred on account of their involvement and idea of school health activities regardless of their geographical location. The teachers in collaboration with healthcare professional are those responsible for the implementation of school health curriculum. Again, corona is quite contemporary that some might have broader knowledge as people were following the issues concerning the spread in all media closely than others.

\section{Problem Statement}

Globally, the number of COVID-19 related deaths are over 3million. No country or sector is left untouched, yet it seems the pandemic is far from over according to BBC report (2021). Earlier on, UNICEF, (2020) acknowledged that "more than 1 billion children are at risk of falling behind due to school closures aimed at containing the spread of COVID-19. To keep the world's children learning, countries have been implementing remote education programmes. Children from poor background lacked internet access, personal computer or radio at home, which amplified existing learning inequalities as such children have no means to continue their home-based education. In some instances, there was outright school dropouts, undoing years of progress made in education around the world". Considering these data, it is important that countries and states should not rely on any single measure to prevent the spread of COVID-19 in schools. 
Schleicher (2020), states the impact of COVID-19 on education such as: increase public finance, children from disadvantaged backgrounds often remained shut out when their schools shut down across 188 low, middle and high income countries. In addition, the longrun economic impact of this loss of the equivalent to one-third of a year of schooling for the current student cohort would be because learning loss will lead to skill loss, and the skills people have related to their productivity, gross domestic product (GDP) could be $1.5 \%$ lower on average for the remainder of the century. Moreover, studies are still underway to assess the risk of infection in children and to better understand transmission in this age group.

As a public health specialist, a lot of schools are seen not adhering to the prevention protocol. Children and teachers are standing on line during early morning devotion without face mask or shield. Seemingly, Bayelsa State which recorded her index case in May 2020, only Oyeyemi, Adesina and Ogoina (2020) which talked on a "rethink on schools focusing on fumigation" as a means of prevention is the only article that was identified in this regard. Thus, there is every possibility of school children spreading the virus, if schools are not proactive, as such the need to conduct this study.

\section{The Objective of the Study}

The objective of this article is to explore and describe responses from participants who are healthcare and educational participants on measures that should be adopted in elementary and secondary schools to prevent the spread of Covid-19.

The study will add value to school healthcare promotion, it will create new knowledge and increase awareness on the need for protection of school children. Likewise, it will promote skills development, proficiency, self-efficacy and motivation to adopt measures in consonance with WHO`s best practices. Most expediently, Schools in the area will be termed health promoting schools (Agency for Healthcare Research and Quality, 2012).

\section{Methodology}

A qualitative design, exploratory and descriptive research approach was employed to elicit responses from participants who are healthcare and educational professionals on measures that should be adopted in elementary and secondary schools to prevent the spread of Covid19 in Bayelsa state, Southern Nigeria. Brink, Van der Walt, and Van Rensburg (2012) and Creswell (2017) state that, qualitative research design is relevant for exploring, describing and comprehending as well as demarcating a prodigy, to give an insight on the phenomenon.

\section{Population and Sampling}

The target population for the study involved healthcare professionals and professional teachers. A non-probability purposive sampling technique was used to recruit eligible participants regardless of geographical location. Only healthcare personnel and elementary/secondary school teachers were stated as eligible to participate purposively owing to their interaction with school children and direct involvement in the promotion of school health. Students were excluded from participating in the study because they are not responsible for the implementation of the school health programmes and activities. 


\section{Data saturation}

At the $32^{\text {nd }}$ Facebook participant, thematic data saturation was achieved, as no new information was elicited from participants. In other to be certain of information was saturated, researchers further received four (4) more in order not to miss out relevant information. A total of thirty-six (36) participants responded.

\section{Data Collection}

An online-question was put forwarded as an interview to obtain data from $1^{\text {st }}$ of April to $4^{\text {th }}$ of May 2020 to allow as many that are willing to participate in the study. Instruments were a semi-structured open ended question that was thrown into WhatsApp and Facebook platforms to receive responses from participants whenever anyone responded. For the sake of uniformity and consistency, both platforms were sent the same question as follows: "What measures that should be adopted in elementary and secondary schools to prevent the spread of Covid-19 (State your profession-teachers in elementary and secondary and all healthcare professionals only please)?" The question was displayed and daily brought forwarded to serve as reminder for a period of one month and four days, because, researchers took into consideration of some irregular platform users and also people who go on those platforms only at their convenient times. Few (one or two) probing questions were forwarded through repeated chat to clarify unclear statements through same platforms.

\section{Data Analysis}

Data collection and analysis were simultaneously conducted in this study adopting Tesch's six step method of line-by-line thematic analysis (Creswell and Plano Clark, 2017). The steps included retrieving and verbatim transcription of data elicited from various participants and platforms to make sense of the information, the responses were gathered to make a single document. In step two (2), categories that emanated were highlighted for easy identification from the data in colours to create coding scheme. In step three (3), similar categories were clustered together. In step four (4), themes and sub-themes identified. Step five (5) the main themes and quotes that best illustrated the meaning of each category were identified. At the sixth (6th) step, report was given under discussion segment of this study.

\section{Ethical considerations}

This study never involved human beings' physical presence, thus ethical approval was not applicable. To maintain a considerable level of ethical practice, researchers ensured all sources were duly referenced both at the in-text and at main referencing page. For anonymity sake, participants 'names were expunged and replaced with acronyms such as Participant 1 (P1, 2, to the $36^{\text {th }}$ participant.). Again, no one was coerced into the study. The question was thrown into the two platforms and those willing participated and each participant sent their responses through same medium, within a space of one month and four days.

\section{Trustworthiness}

Trustworthiness was ascertained through confirmability, dependability, credibility and transferability as proposed by Denzin and Lincoln's (2011) framework. To ensure confirmability or audit trail, transcript and the table of analysis are added for verification by any interested person (s), which indicates, the whole idea was not in any way tampered with, 
it was purely the participants`idea. Also, sub-themes and main themes creation processes are clearly presented in the appendix. Besides this, this article was developed by public health professionals. For dependability, all authors were involved in the clearly presented coding process.

Patton (1999), defines literature control as a comparison of the findings of a study with previously existing literature. In this study, the qualitative responses were used to ascertain the findings and acknowledged existing literatures. Below is the presentation of findings

\section{FINDINGS}

Table 1: Interviews conducted with the participants according to the characteristics (platforms and professions).

\begin{tabular}{|c|c|c|c|c|}
\hline Participant & $\begin{array}{l}\text { Profession } \\
\text { Education }\end{array}$ & $\begin{array}{l}\text { Profession } \\
\text { Health }\end{array}$ & $\begin{array}{l}\text { Platform } \\
\text { WhatsApp }\end{array}$ & $\begin{array}{l}\text { Platform } \\
\text { Facebook }\end{array}$ \\
\hline \multirow{2}{*}{$\begin{array}{l}\text { Participant } 1 \\
\text { P } 2\end{array}$} & & $H C$ & $=$ & \\
\hline & & $=$ & $=$ & \\
\hline P3 & & $=$ & $=$ & \\
\hline P4 & $\mathrm{T}$ & & $=$ & \\
\hline P5 & $=$ & & $=$ & \\
\hline P6 & $=$ & & $=$ & \\
\hline P7 & $=$ & & $=$ & \\
\hline P8 & & $=$ & $=$ & \\
\hline P9 & & $=$ & $=$ & \\
\hline P10 & & $=$ & $=$ & \\
\hline P11 & $=$ & & $=$ & \\
\hline P12 & & $=$ & $=$ & \\
\hline P13 & & $=$ & $=$ & \\
\hline \multicolumn{5}{|l|}{ P14 } \\
\hline P15 & & $=$ & $=$ & \\
\hline P16 & & $=$ & $=$ & \\
\hline P17 & $=$ & & & $=$ \\
\hline P18 & $=$ & & & $=$ \\
\hline P19 & & $=$ & & $=$ \\
\hline P20 & & $=$ & & $=$ \\
\hline $\mathrm{P} 21$ & & $=$ & & $=$ \\
\hline $\mathrm{P} 22$ & $=$ & & & $=$ \\
\hline $\mathrm{P} 23$ & & $=$ & & $=$ \\
\hline P24 & $=$ & & & $=$ \\
\hline $\mathrm{P} 25$ & $=$ & & & $=$ \\
\hline P26 & $=$ & & & $=$ \\
\hline P27 & & $=$ & & $=$ \\
\hline P28 & & $=$ & & $=$ \\
\hline P29 & & $=$ & & $=$ \\
\hline P30 & T. Admin & & & $=$ \\
\hline P31 & & $=$ & & $=$ \\
\hline P32 & $\mathrm{T}$ & & & $=$ \\
\hline P33 & $=$ & & & $=$ \\
\hline
\end{tabular}




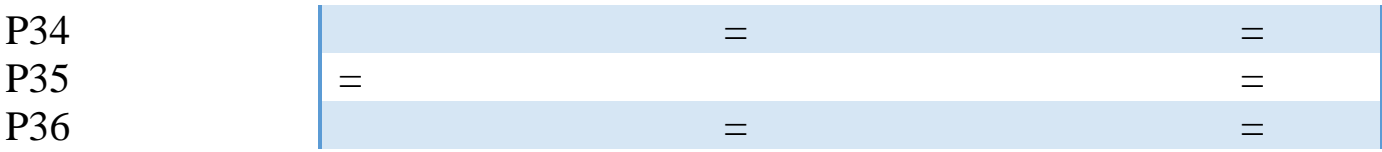

N/B P-participant; W-WhatsApp; F-face-book; T Admin-Teacher administrator; T-teacher; HC- healthcare professional.

\section{Characteristics of participants}

From the study, it was found that sixteen (16) of the participants responded through WhatsApp platform and twenty (20) from Facebook. Invariably, there were no persons below adolescence, given, the criteria to open account in any of the platforms aforementioned is restricted to certain age limit on moral grounds. Moreover, participants tune of responses indicate, they have served for a considerable number of years in either the healthcare or teaching fields. The teacher administrator is a trained teacher who was transferred to administrative office of the school.

Similarly, both healthcare professionals and those from teaching professions were part of the voluntary participants. The healthcare professionals were from various sectors of the healthcare delivery system, which includes; Registered Nurses, Midwives and School health/public health nurses as well as Community health extension workers. Others are physicians of various specialty areas and those of the allied medical professions also participated in the study.

In addition, the findings indicate that the teachers who participated cut across both the private and public elementary and secondary schools. Not only teachers responded, but participants from other units affiliated to the teaching institutions (administrator) such as the member of the national orientation agency added voice owing to the importance attached to this study.

Furthermore, the participants were not localized, judging the fact that, some participants were from outside the shores of Nigeria. Gender, religion or number of years in their chosen professions were not part of the criteria, for the reason that prevention of COVID-19 has become a new world order that involves collective action.

The findings of this qualitative study yielded five (5) themes as follows: Preventive measures: awareness and knowledge creation: effective information and management system: availability of drugs and other amenities: monitoring and evaluation. thirteen (13) sub-themes emerged from the five themes.

\begin{tabular}{|c|c|}
\hline Themes & Sub-themes \\
\hline 1. Preventive Measures & $\begin{array}{l}\text { 1. Fumigation of school premises } \\
\text { 2. Washing hands and wearing of face mask } \\
\text { 3. Maintain social distancing } \\
\text { 4. Proper screening before resumption. }\end{array}$ \\
\hline 2. Awareness and knowledge creation & $\begin{array}{l}\text { 1. Health Education and sensitization of } \\
\text { pupils/students. } \\
\text { 2. Use of existing framework and compliance }\end{array}$ \\
\hline
\end{tabular}




\begin{tabular}{|c|c|}
\hline $\begin{array}{l}\text { 3. Effective information and } \\
\text { management systems }\end{array}$ & $\begin{array}{l}\text { 1. Institutionalization of effective information } \\
\text { system } \\
\text { 2. Use of existing governmental agencies. } \\
\text { 3. Quality assurance }\end{array}$ \\
\hline $\begin{array}{l}\text { 4. Availability of drugs and other } \\
\text { amenities }\end{array}$ & $\begin{array}{l}\text { 1. Production of drugs } \\
\text { 2. Effective treatment }\end{array}$ \\
\hline 5. Monitoring and evaluation & $\begin{array}{l}\text { 1. Monitoring activities } \\
\text { 2. Evaluation }\end{array}$ \\
\hline
\end{tabular}

\section{Theme 1: Preventive Measures}

Sub-theme 1: Fumigation of school premises

Participants suggested that fumigation of elementary and secondary school premises would be a good feat in the prevention of Covid-19 in Bayelsa State, considering that, the fumigant will control stored virus products. However, one participant never indicated the type of fumigant, whereas, the others mentioned the type(s) as captured in the excerpts below:

\section{"Fumigation of school premises" (PW1).}

"Schools should ensure the following:

Maintain good indoor ventilation. Windows of class should be opened for ventilation, switch on fans to enhance air flow, keep air conditioners well maintained, clean the dust filters of air-conditioner regularly. Environmental cleaning and disinfection; keep classrooms, kitchens, canteens, toilets and bathrooms clean and hygienic. School management is advised to maintain good hygienic standards of school premises. Through thorough cleaning and disinfection daily. Clean and disinfect frequently touched surfaces, furniture, toys commonly shared items and floor at least daily by using appropriate disinfectant. For non-metallic surface, disinfect with 1 part of 5.25\% household bleach in 99parts of water wait until dry and then rinse with water. For metallic surfaces, disinfect with $70 \%$ alcohol. If places are contaminated with respiratory secretions, vomitus or excreta, use strong absorbent disposable towels to wipe them away. Then disinfect the surface with the neighboring area with appropriate disinfectant. For non- metallic surface, disinfect with 1 part of 5. 25\% household bleach in 49parts of water, leave it for 15-30minutes and then rinse with water. For metallic surfaces, disinfect with $70 \%$ alcohol. for hand hygiene practices: provide liquid soap and disposal paper towels. Or hand dryers at places where there are hand washing facilities. Eg. Toilets, kitchens/pantries, laundries, art rooms as indicated. Provide alcohol-based hand-scrub in places where hand washing materials are available. 70-80\% alcohol based hand-scrub is effective" (P16 W)

Sub-theme 2: Washing of hands

Not less than eleven (11) participants suggested the need for elementary or secondary schools to ensure school pupils/students wash hands regularly and put on their face mask to prevent the spread of COVID-19 in school premises. Some participants mentioned the two variable (washing hands and face mask) singly under this sub-theme, whereas others mentioned it together. Example, 
"I am a teacher ooo, children and teachers should clean hands, wear mask, teach children to cover Nose and mouth while coughing and sneeze safely. Also keep distance and open windows to beat covid-19 in schools" (P32fb).

Sub-theme 3: Maintain social distancing

Since people generally and school children can harbor and spread the virus before they know they are sick, it is important to stay at least six (6) feet or two (2) meters away from others when possible, even if the children do not have any symptoms. Maintain social distancing is important for people who are at higher risk for severe illness from COVID-19. It was recommended that stakeholders maintain social distancing to prevent the spread of Covid-19 in elementary and secondary schools whenever schools are in session. Some quotes to that effect are below.

"Social distancing, wearing of face mask/shield and washing of hands before entering classrooms. it is reasonable to resume schools but with particular attention paid to social distancing and protective face mask usage" (P31fb).

“.......no classroom should exceed 20 students" (P16W).

Sub-theme 4: Proper screening before resumption.

Maintaining a healthy school environment is incontestable in this new world order on account of the COVID-19. Some participants recommended proper screening of pupils/students upon resumption of schools as a preventive measure to curb the menace of Covid-19 in elementary and secondary school environments. According to the participants,

"daily temperature checks and other routine observations should be done after devotion before the kids starts classes for the day. Because, the kids come from homes where they interact with relatives each day" (P11W, P2W, P3W). Daily temperature checks on resumption on both staff and students should be carried out (P16W).

\section{Theme 2: Awareness and Knowledge Creation}

A good number of participants attest the fact that, awareness and knowledge creation with regards to the etiology and ravaging effect are appropriate to curb the spread of COVID-19 in school environment. Two (2) sub-themes emanated from this theme - Health Education/ sensitization of pupils/students and use of existing framework and compliance

Sub-theme 1: Health education/sensitization

A good number of participants attested that health education and sensitization are measures schools can adopt to prevent the spread of Covid-19 in schools. Below are few quotes from participants.

"as a teacher, I recommend, Health Education and sensitization of pupils, students and teachers including parents on best preventive practices after physical education lesson" (P5W). 
"my opinion though. First, health education is the utmost here to create awareness on how to contain the spread of CovID-19 virus. Also encourage students confront and discourage stigma and also to incorporate relevant health education into other subjects" (P12W).

".......and also the concept of diseases prevention and control, you can use exercises that demonstrate how germs can spread. For example, you can put coloured water in a spray bottle and spray it on a piece of white paper and observe how far the droplets travel" (P13W).

Sub-theme 2: Use of existing frameworks

A substantial proportion of the activities in the response framework focused on the harmonization of response across the various partners and the National, State and LGA. Some participants suggested the need of using the existing framework and enforcement of existing laws. For instance,

“adoption of frameworks. Health Belief model and Donabedien framework" (P9W).

Repeat ..." Enforcement of existing COVID-19 preventive protocols" (P22)

"The framework should be WHO compliant so as to prevent litigation(s)" (P7W).

"I for one as a healthcare practitioner, let the resumption date be extended till further notice. Hello Helen, this is my candid opinion because, we are not sure of the compliance of the WHO preventive guidelines. Not only that, we as Nigerians, we do not have the capacity to enforce the existing government laws, so no point deceiving ourselves, let the children simply be at home" $(\mathrm{P} 21 \mathrm{fb})$.

"Adopt framework. Donabedian's (2005) three components approach for evaluating the quality of care underpins measurement for improvement. The three components are structure, process and outcomes. ..." (P8W)

\section{Theme 3: Effective Information and Management System}

Participants also were of the opinion that effective information management system should be put in place, which will go a long way in preventing the spread of the virus in school environments. Three (3) sub-themes emanated from this theme - Institutionalization of effective information system, use of existing governmental agencies and quality assurance.

Sub-theme 1: Institutionalization of effective information system

"(i) strengthen efforts to increase, domestication of recording and vital information structures; (ii) reinforce monotonous health evidence structures; These would involve and engage stakeholders to ensure their opinion counts. It is also is considered one of the most important aspects of quality care. Clear, comprehensible information and support for selfcare...." (P36fb).

Probe- Can you expatiate on these?

"...am not yet done, its my data that finished and my face-book stopped. Schools should shorten the children's contact hours. Schools should close early every day such as twelve" (P36fb). 
Sub-theme 2: Use of existing governmental agencies.

These are government owned establishments that are engaged to carry out designated functions aimed at ordering state programmes. Using the existing agencies can ensure a program success since the program use existing information and resources to achieve its aim in access and quality. Participants also recommended the need to use the National Orientation Agency to sensitize the public and schools to prevent the spread Covid-19 in schools as quoted below.

"National orientation agency should live up to expectation. They should sensitize the public, especially the school children during school hours of the effect of COVID -19” (P30)

Sub-theme 3: Quality Assurance

Quality assurance was recommended by participants as a measure to prevent COVID-19 in elementary and secondary schools. See quote below,

"Adopt framework. Donabedian's (2005) three components approach for evaluating the quality of care underpins measurement for improvement. The three components are structure, process and outcomes. ..." (P8W).

\section{Theme 4: Availability of Resources}

Two (2) sub-themes emerged from this theme. Availability of drugs and other amenities was identified as a theme, judging that a good number of participants attested to this as a means that could be adopted to prevent the spread of the infection. Below are the sub-themes and the quotes.

Sub-theme 1: Production of drugs

Some participants recommended that vaccines (drugs) should be made available in order to prevent the likelihood of spread of COVID-19 in schools as stated below,

"Let the government expedite the production of vaccines and let them stop playing politics with this whole covid-19 issue. Prevention is possible if these are done" (P23fb).

There are vaccines provided for such pandemics. Why can ensure all children are immunized. Although no vaccination for now. Let there be mass production of vaccines for school children. government can do that if they make it a priority (P29fb).

"Government should ensure running water in schools" (PW2)

"Let both teachers and staff and school children wash hand-but this will be possible if the government can provide regular supply. Otherwise, it will be difficult” (P26fb).

Sub-theme 2: Effective treatment

Some participants opined that effective treatment of identified cases in the prevention of infection will be appropriate. See quote,

"............ Staff and children should seek prompt medical attention for treatment if they develop fever or respiratory infections symptoms" (P16W). 


\section{Theme 5: Monitoring and Evaluation}

These management processes, monitoring and evaluation activities were identified as some measures to prevent COVID-19 spread in school environment by a good number of participants.

\section{Sub-theme 1: Monitoring}

Monitoring is the act of carrying out surveillance and recording of activities aimed at improving procedural standards. Participants emphasized the need for teachers to monitor pupils/students to ensure social distancing, and other protective measures are complied appropriately. are

"Teachers to monitor students during break times to ensure social distancing. If social distancing cannot be maintained during break, then students should wear nose mask

"Have students analyze text to identify high risk behaviour and suggest ways to change them. For example, a teacher comes into school with a cold, he sneezes and covers it with his hands, he shakes hands with a colleague, he wipes his hands with an handkerchief, then goes to class to teach" (P6W).

"My opinion though. ..................Finally, monitoring and surveillance systems very important. Sanctions must be placed on defaulters" (P12W)

Sub-theme 2: Evaluation

Evaluation is a logical process of collecting, analyzing and interpreting data to determine the extent to which pupils/students achieve instructional objectives. At least two participants recommended the need for evaluation activities to ensure COVID-19 preventive exercise has taking place.

"Have students analyze text to identify high risk behaviour and suggest ways to change them. For example a teacher comes into school with a cold, he sneezes and covers it with his hands, he shakes hands with a colleague, he wipes his hands with an handkerchief, then goes to class to teach" (P13W).

"Ask the students, What did the teacher do that was risky? What should he have done instead?’?(P13W)

"First is to review data from primary and secondary schools in terms of number of learners per grade with their demographics. Secondly, review the physical infrastructures with the size of classroom, chairs and tables with the thinking of social distancing as recommended by WHO. Review of personnel and their roles with the admin, teaching and support staff then plan for options; which could be remote teaching, virtual or distance learning. If infrastructures will affect, plan in a phase in approach to which grade comes in at what week. Priority should be in grades. Nursery 2, primary 5 and 6, ss 3 and jss3. Teachers to monitor students during break times to ensure.... " (P14W)

"Adopt Donabedien framework. Donabedian's (2005) three components approach for evaluating the quality of care underpins measurement for improvement. The three components are structure, process and outcomes. ..."(P8W). 


\section{DISCUSSION}

This qualitative study, participants offered measures elementary and secondary schools can adopt in order to prevent the spread of COVID-19 within school environment and by extension to the larger society under five (5) themes and thirteen (13) sub-themes. The findings indicate lots of commonalities with slight variability. The commonalities are observed from participants' professions and the platforms through which the data was elicited and the professions. The commonalities could be the offshoot of the eligibility criteria.

A good number of participants` recommendation revealed that adopting appropriate measures would prevent the spread of COVID-19 in both private, public elementary and secondary schools. Some of the participants recommended one preventive measure that could be adopted in order to curb the rapid spread of corona virus. Whereas, others mentioned more than one measure. Notable of such preventive measures participants recommended was fumigation. Fumigation is a method of applying gaseous pesticides or fumigants for disinfection of physical structures to suffocate Corona virus. One participant never recommended any specific method or chemical for the fumigation, but another recommended the use of 1part of 5. 25\% household bleach in 49parts of water, leave it for 15-30minutes to disinfect the area on metallic surfaces. According to the participant, for non-metallic surfaces, disinfect with 1 part of 5.25\% household bleach in 99parts of water wait until dry and then rinse with water. This finding is consistent with Oyeyemi, Adesina and Ogoina (2020), which states that "many state governments and school owners are fumigating their schools as a measure of disinfecting the school environment and ensuring safe resumption of academic activities".

Again, social distancing of school children was recommended by participants as a measure to prevent the spread of COVID-19 in schools. Several methods of social distancing were mentioned ranging from "classrooms not exceeding 20 students", early school closure to alternating morning and evening sessions. These are consistent with Gray, Kurscheid, Mationg, et al. (2020), which affirmed maintaining social distance in school could prevent COVID-19.

Moreover, proper screening before resumption of school was recommended by participants as a measure to prevent COVID-19. According to the participants screening and testing all pupils/students are some best ways to ensure safety of all school children, teachers and personnel and went on to mention daily temperature check as part of the measure due to peculiarity of COVID-19. This assertion is consistent with a recent study conducted by the American Academy of Paediatrics (2015) which ascertain the types of screening exercises conducted upon resumption of schools to exclude dental issues, skin diseases, sight, hearing and other neurological issues. These imply that screening recommended by participant is a good approach to detect carriers and sufferers of COVID-19.

In addition, a good number of participants recommended awareness and knowledge creation as measures to prevent the spread of COVID-19 in schools. However, judging from their point of view, approach such as health education and sensitization would be appropriate. Health education and sensitization are important components of disease prevention activities in general, but during disease outbreaks and health emergencies, they play a key role in an active response by offering well-established tools. These are also in consonance with Gray, Kurscheid, Mationg, et al. (2020) study which claimed, messaging specifically targeting 
children who may well be acting as "silent" transmitters of COVID-19 are presently lacking. Thus, a video/cartoon-based entertainment-education intervention would fill this need. The findings also indicate, health education and sensitization are important variables in the promotion of school health through health talks on disease etiology, prevention and control. It also involves enlightening parents, school children, teachers and other allied staff. These groups could demonstrate how germs can spread. For example, you can put coloured water in a spray bottle and spray it on a piece of white paper and observe how far the droplets travel. These can be inferred that awareness and knowledge creation through health education of children and sensitization of parents, teachers and other personnel in school can prevent the spread of COVID-19 to a very large extent.

Another sub-theme under awareness and knowledge creation is the use of existing framework and compliance to prevent the spread of COVID-19 in elementary and secondary schools. Some of the participants recommended health belief model, others recommended the adoption of Donabedian's (2005) three components framework, whereas others recommended adherence strictly to WHO guidelines. The participant that recommended Donabedien framework added the need to utilize the three components that are inbuilt (structure, process and outcomes) in the framework. Whereas, the participant that recommended the WHO guideline further state, Nigeria is a State where citizens disregard directives, hence reaffirmed the need for enforcement of existing frameworks for compliance to prevent litigation (s) and for the school children to be at home. This is consistent with chapter six (6) "compliance, enforcement appeal" of "Better regulation in Europe: The Netherlands Organization for Economic Co-operation and Development (OECD) (2010) article, which states that, despite the fact that adoption and communication of an edict sets the framework for achieving a policy objective. Thus, effective execution, compliance and enforcement of COVID-19 laws made by WHO are key for actually achieving the stated prevention in school objectives. In other words, to prevent COVID-19 in elementary and secondary schools, adoption, enforcement and compliance of existing frameworks are inevitable.

Besides these, a participant recommended effective information and management system as measures to prevent COVID-19 in schools. The institutionalization of health information system is possible only if it is sustained and legitimated by organizational actors and individuals. This is consistent with MEASURE Evaluation-USAID (2016) article on "aligning Stakeholders for Health information systems strengthening: one step at a time". The article states that "Strong and legitimate health information systems are the mainstay in health systems. Therefore, properly functioning healthcare delivery system sends the right information into the right hands at the right time and enables stakeholders to make informed choices about COVID-19 prevention in school environment.

In addition, participants recommended the need to use the National Orientation Agency to sensitize public and schools to prevent the spread of Covid-19. Using the existing agencies can ensure a program success since the program use existing information and resources to achieve its aim in access and quality. The participant's view is that, the National Orientation Agency should sensitize the general public to achieve the maximum prevention benefits. In so doing, COVID-19 can be prevented in schools.

Quality assurance is one recommendation made by participants that would prevent COVID19 in schools. Quality assurance is the maintenance of a desired level of quality in a service or product, especially by means of attention to every stage of the process of delivery or 
production. Although specific method quality assurance framework was recommended. This is consistent with Guru (1999) anecdotal article that quality assurance is a way of preventing mistakes and defects in manufactured products and avoiding problems in a program.

Another theme that gained prominence as a recommendation offered by participants is availability of resources. The availability of resources plays a pivotal role in resource management, be it material, human and sundry. It also serves as an important factor at any given time, it is relevant in deciding how to distribute and allocate the right assets for any given health programme. Some participants` recommendation are for government to expedite the production of vaccines, whereas, others recommended the supply of other facilities that would promote keeping COVID-19 prevention protocols such as regular water supply. The supply of necessary resources is consistent with a way-back study that is relevant till date conducted by McCallum, Rusbult, Hong, Walden and Schopler (1979). The authors reasoned that, when needed resources are not made available, it could course programme setback. It means that, if vaccines and other resources are supplied, it would expedite the programmes developed by WHO and governmental agencies to prevent COVID-19 simply because, teachers and school health personnel would look at resource availability thoroughly to ensure prevention programmes are given needed attention.

Another participant recommends effective treatment of sick children. However, the participant was not categorical as to whether the effective treatment was on children who had COVID-19 or other illnesses. Even though the possibility of children showing full blown COVID-19 is slim, it is perceived they can harbor the virus through family members and are likely to transmit to others. Thus, the participant recommended that peradventure any school child on resumption shows any sign of ill-health, such school pupil/student should be adequately treated in order to prevent the spread of COVID-19 in school environment. This is consistent with an article written by Story (2020), which emphasizes that a sick school child should be kept at home from school to help them recover faster and prevents the virus from spreading to other children in the school.

Monitoring and evaluation were recommended by a number of participants as ways to prevent the likely spread of COVID-19 in school environment. At least two participants recommended monitoring and three recommended evaluations explicitly. The participant who recommended monitoring were explicit on the need to monitor students during breaks to ensure they adhere to rules of COVID- 19 prevention with regards to social distancing, further stresses the need for teachers to ensure school children understand risky behaviour through analysis of write-ups and demonstration of preventive measures. Others were specific-added that monitoring and surveillance system are essential and any defaulter of COVID-19 protocols must be sanctioned unequivocally. Whereas, those participants who recommended evaluation as a means to prevent the spread of COVID-19 in elementary and secondary schools believes that asking students what they learned from a particular activity for them to say is an evaluating approach aimed at identifying the level of students` understanding of the approach, reviewing of data and assessment of infrastructure. These assertions can be deduced that practical steps in implementing monitoring and evaluation activities can identify relevant indicators for improvement in the prevention of COVID-19 in schools.

This is consistent with WHO (2006) "monitoring and evaluation of communicable diseases' guide" which states that monitoring and evaluation helps to track activities, identify problems 
in the system in order to institute corrective measures in a timely manner and document the status of, and any change in the performance of the system. Also monitoring and evaluation provide an evidence-base on which to modify surveillance objectives, implementation of planned activities and provide explanations for achievements and failures as well as provide specific recommendations for improving the school system in the area of prevention of COVID-19 in elementary and secondary schools.

\section{REFERENCES}

African Union (2021). African Union Member States Reporting on COVID-19 cases. www.africacdc.org. Retrieved 16 January 2021.

Akani, N.A., Nkanginieme, K.E.O. \& Oruamabo, R.S. 2001. The school health program: A situational revisit. Nigerian journal of pediatrics. 28(1): 1-6.

Alex-Hart, B.A \& Akani, N.A. 2011. An evaluation of health status of school environment in public primary school in bonny local government area, Rivers State. The Nigerian Health Journal, 11(3):2-6.

American Academy of Paediatrics (2015) Health Screenings at School.

Better regulation in Europe: The Netherlands OECD (2010). Compliance, enforcement, appeals. Chapter 6.

Commission on Chronic Illness. (1957) Chronic Illness in the UnitedStates. Vol. I. Prevention of Chronic Illness. Cambridge, Mass.:Harvard University Press.

Gray, D.J., Kurscheid, J., Mationg, M.L. et al. (2020) Health-education to prevent COVID-19 in schoolchildren: a call to action. Infect Dis Poverty9, 81.

https://doi.org/10.1186/s40249-020-00695-2.

https://www.healthychildren.org/English/Pages/default.aspx. Retrieved $14^{\text {th }}$ May, 2021. https://www.who.int/emergencies/diseases/novel-coronavirus-2019/interactive-timeline\#! Krishnaratne, S., Pfadenhauer, L. M., Coenen, M., Geffert, K., Jung-Sievers, C., Klinger, C., ... \& Burns, J. (2020). Measures implemented in the school setting to contain the COVID-19 pandemic: a scoping review. Cochrane Database of Systematic Reviews, (12).

Lessler K. (1972). Health and Educational Screeningof School-Age ChildrenDefinition and Objectives. African Journal of Public Health.

McCallum R, Rusbult C E, Hong G K, Walden T A and Schopler J. (1979). Effects of Resource Availability and Importance of Behavior on the Experience of Crowding. Journal of Personality and Social Psychology 1979, Vol. 37, No. 8, 1304-1313

Measure Evaluation (2016) Aligning Stakeholders for Health Information Systems Strengthening: One Step at a Time. U.S. Agency for International Development (USAID) under terms of Cooperative Agreement AID-OAA-L-14-00004 and implemented by the Carolina Population Center, University of North Carolina.https://www.measureevaluation.org/resources/publications/fs

Memish ZA, Zumla AI, Al-Hakeem RF, Al-Rabeeah AA, Stephens GM. Familycluster of Middle East respiratory syndrome coronavirus infections. N Engl JMed 2013;368(26):2487-94.

Monticelli, D. D. F. (2020). Estimating asthmatic children exposure and dose to air pollutants in an urban industrialized area (Doctoral dissertation, Federal University of Espírito Santo). 
Oyeyemi, A Adesina A and Ogoina D. 2020. Fumigation of Schools for COVID-19 Prevention in Nigeria: The Need for a Rethink. A Perspective Piece. American. Journal of. Tropical. Medicine and. Hygiene., 103(4), 2020, pp. 13701371doi:10.4269/ajtmh.20-1037.

Panchalingala, S. B. (2020). Bird's Eye View on the Diagnosis, Treatment, \& Prevention of the COVID-19 Outbreak. AIJR Preprints.

Peiris J, Guan Y, Yuen K. Severe acute respiratory syndrome. Nat Med 2004;10(12):S88-97.

Phan LT, Nguyen TV, Luong QC, Nguyen TV, Nguyen HT, Le HQ, et al.Importation and human-to-human transmission of a novel coronavirus inVietnam. N Engl J Med 2020.

Pyrc K, Berkhout B, Van Der Hoek L. Identification of new human coronaviruses. Expert Review of Anti-infective Therapy 2007;5(2):245-53.

Rahman A, Sarkar A. Risk factors for fatal middle east respiratory syndromecoronavirus infections in Saudi Arabia: analysis of the WHO Line List, 2013-2018. Am J Public Health 2019;109(9):1288-93.

Riou J, Althaus CL. Pattern of early human-to-human transmission of Wuhan2019 novel coronavirus (2019-nCoV), December 2019 to January 2020.Eurosurveillance. 2020;25(4).[13] Parry J. China coronavirus: cases surge as official admits human to humantransmission. British Medical Journal Publishing Group; 2020.

Scheleicher A. (2020) The impact of COVID-19on education - Insights fromEducation at a Glance 2020. OECD. Available at https://www.oecd.org. Accessed 19 ${ }^{\text {th }}$ May, 2021.

Shereena MA., Khana S, Kazmic A, Bashira N and Siddiquea R. (2020). COVID-19 infection: Origin, transmission, and characteristics of human coronaviruses. Journal of Advanced Research 24 (2020) 91-98,

Sowole, S. O., Ibrahim, A. A., Sangare, D., \& Johnson, I. O. I. F. I. Understanding the Early Evolution of COVID-19 Disease Spread using Mathematical Model and Machine Learning Approaches.

Story C. M (2020). How to Handle School Sick Days? Healthline. Available at https://www.healthline.com/health/cold-flu/school-sickdays. Retrieved $16^{\text {th }}$ May, 2020.

Umeizudike, K. A., Isiekwe, I. G., Fadeju, A. D., Akinboboye, B. O., \& Aladenika, E. T. (2020). Nigerian undergraduate dental students' knowledge, perception, and attitude to COVID-19 and infection control practices. Journal of dental education.

UNICEF, (2020) EDUCATION AND COVID -19.UNICEF Data: Monitoring the situation of children. Available at womenhttps://data.unicef.org/topic/education/covid-19. Accessed $19^{\text {th }}$ May, 2021.

UNICEF. Statistics Education (2018). Available from: https://data.unicef.org/topic/education/primary-education/. Retrieved 26 ${ }^{\text {th }}$, April 2021/

Viner, R. M., Russell, S. J., Croker, H., Packer, J., Ward, J., Stansfield, C., ... \& Booy, R. (2020). School closure and management practices during coronavirus outbreaks including COVID-19: a rapid systematic review. The Lancet Child \& Adolescent Health.

Wang C, Horby PW, Hayden FG, Gao GF. A novel coronavirus outbreak of globalhealth concern. The Lancet 2020.

WHO (2006) Communicable disease surveillance and response systems. Guide to monitoring and evaluating. Available at www.who/cds/epr/lyo. Retrieved $16^{\text {th }}$ May, 20221.

WHO 2020. WHO Coronavirus Disease (COVID-19) Dashboard

World Health Organization, (2020). Organization WH. Laboratory testing for coronavirus disease 2019 (COVID-19) in suspected human cases: interim guidance, 2 March 2020.

Yamey, G., \& Walensky, R. P. (2020). Covid-19: re-opening universities is high risk. 